\title{
EFFECT OF PARTIAL REPLACEMENT OF CORN BY BISCUIT WASTE (BW) ON NUTRIENTS DIGESTIBILITY, MILK PRODUCTION AND ECONOMICAL EVALUATION IN LACTATING DAMASCUS GOATS
}

\author{
Haiam A. Sayed, A. M. Hussein, M. M. El-Maghraby , R. I. Matari and M.M. Elbadawy \\ Animal Production Research Institute, Ministry of Agric., Dokki, Giza, Egypt.
}

(Received 12/7/2021, accepted 16/9/2021)

\section{SUMMARY}

$\mathrm{T}$ Wenty- four Damascus goats at late pregnancy period with live body weight on the average $(44 \pm 2 \mathrm{Kg})$. Were divided into three similar groups according to their body weight ( 8 goats each) for 90 days trial. The experimental concentrate feed mixture (CFM) offered to animals without or with the rate of replacement 20 (R2) and 40\% (R3) Biscuits waste (BW ) of corn. The basal rations composed of $60 \%$ concentrate feed mixture (CFM) and $40 \%$ clover hay. Digestibility trials were carried out at the end of experiment using acid insoluble ash (AIA) technique. Data showed that significant higher digestibility (P <0.05) of DM, CP, EE and NFE for BW supplementation compared with control, while decrease digestibility $(\mathrm{P}<0.05)$ of CF. Milk yield was higher significantly in R2 ( $20 \%$ replacement) than the control, there was no significant difference on fat $\%$ while decrease in protein $\%$ in the same treatment . Values of concentrations of blood plasma total protein and Albumin , cholesterol, triglycerides and total lipids of experimental goats were higher with feeding on 20 and $40 \%$ corn replacement than the control. Generally, it could be concluded that the replacement of corn by BW at level 20\% in rations for dimishki goats improved digestibility, feeding values and milk yield and its composition.

Keywords : Biscuits waste, Goats, Digestibility, Milk yield and Blood parameters.

\section{INTRODUCTION}

The food industry produce a large amounts of by-products, which causing environmental problems. Using it as raw materials help us to formulate low cost animal feeds. In the mean time, it decrease the environmental pollution and improving value of this by- products (Deise et al, 2017)

Ruminants can turn unsuitable and unpalatable feeds into high-quality animal products (milk or meat). The milk production efficiency is calculated as percent between milk nutrients composition and nutrient intake. Caio et al (2019).

In intensive ruminant production systems the use of high amounts of energy-rich concentrates (cereal grains) is necessary. The strategy to cover the requirements of high-producing animals was reducing the food. competition between ruminants and humans is depending on energy-rich by-products in the diets. (Arosemena et al, 1995). Wastes from bakeries such as breads, cake and biscuits which expired also, the wastes of breaking during processing use as energetic feed because it had high concentration of carbohydrates and fat (Wing, 1965).

Biscuits wastes is high energy feed contain milk powder, flour, fats, sugar, flavor materials and salt. The cost of formulated diet with biscuits is lower than those contained maize because it is considered by product from the bakery industry. Using biscuit wastes instead of maize had potential role in decrease the competition between human and animal for traditional feed sources. Shittu et al, 2016)

Dairy cows fed biscuits wastes instead of corn had same milk yield and dry matter intake (DMI) compared to those fed traditional diets, also, using by-product in diet increased the conversion ratio of unsuitable food for humans into useful animal product (Ertl et al,, 2015). Diet of goats when the concentrate portion was replace with bakery waste exhibited improving in $\mathrm{N}$ utilization, feed efficiency and decrease methane production in comparison with a traditional diet (Romero-Huelva et al, 2017). 


\section{Sayed et al.}

In developing countries up to $68 \%$ of the yielded grains fed to livestock (Elferink et al, 2008).According to the population growth feeding grains to animals may be not suitable. So, researchers do their best to find a lot of sustainable feed ingredients (van Zanten et al, 2015).

Using the most suitable raw materials and the feed formulation being factors that effect on efficiency indicators (Pinotti et al, 2019a). There is a trend for waste reduction. This led to increasing in using of these products in the animal feed diets (Organization, 2019).

It is well known that carbohydrates like sugars was more available in the rumen bacteria, fermented faster than fiber or starch in the rumen, the fermentation rates of monosaccharide depending on the type of sugar and rumen environments. Despite fast fermentation in the rumen it able to produce greater fermentable energy and increase microbial protein synthesis.

The objective of this study is to found the effect of partial replacing of corn by biscuit waste (BW) in CFM ( 20 or 40\%) on digestion coefficients, blood parameters and milk production performance of the Damascus goats.

\section{MATERIALS AND METHODS}

The experiment was carried out at Sakha, Animal Production Research Station of Animal Production Research Institute, Agriculture Research Center during summer season of 2020.

\section{Collection and preparation of concentrate feed mixture:}

Biscuit waste (BW) was collected from factory in Sakha. This waste was the residues after processing and cutting biscuits, it was dry and contains chocolate and cream . Corn grains in concentrate feed mixture was replaced by biscuit waste (BW) at $20 \%$ and $40 \%$ (Table1). Biscuit waste (BW), concentrate feed mixture (CFM), clover hay $(\mathrm{CH})$ and feces were analyzed for proximate analysis according to AOAC (1995) whereas, nitrogen free extract (NFE) was calculated by difference

Table (1): ingredients (\%) of the experimental concentrate feed mixture (CFM) in tested CFM.

\begin{tabular}{lccc}
\hline Ingredient & CFM1 (control) & CFM2 $(20 \%$ BW $)$ & CFM3 (40\% BW) \\
\hline Corn & 40 & 32 & 24 \\
Biscuit waste & - & 8 & 16 \\
Wheat bran & 32 & 32 & 32 \\
Sun flower meal & 20 & 20 & 20 \\
Molasses & 5 & 5 & 5 \\
Lime stone & 2 & 2 & 2 \\
Salt & 1 & 1 & 1 \\
Total & 100 & 100 & 100 \\
\hline CFM1: concentrate feed mixture(control), CFM2: concentrate feed mixture $(20 \%$ BW), CFM3: concentrate feed \\
mixture(40\% BW)
\end{tabular}

\section{Experimental rations and animals:}

Twenty- four Damascus female goats at the end of pregnant period divided into 3 groups (8 each) according to live body weight $(44 \pm 2 \mathrm{Kg})$ for 90 days trial. Goats in first group (control) were fed concentrate feed mixture(CFM) consisted of (20\% sun flower meal, $40 \%$ corn grain, $32 \%$ wheat bran, $5 \%$ molasses, $2 \%$ limestone, $1 \%$ salt) and clover hay $(\mathrm{CH})$. In the second and third group corn grain was replaced with biscuits wastes by 20 and 40\%, respectively. Feed was offered at 8 am and 4 pm and the remaining amounts were measured. Water offered ad libitum. The CFM adjusted biweekly according to the body weight changes and milk production. Goats were fed the experimental diets $60 \%$ CFM and $40 \%$ clover hay. Daily feed intakes, milk production, were recorded and feed conversion (g feed/g milk) was calculated. 
Egyptian J. Nutrition and Feeds (2021)

Table (2): Chemical composition of CFM, CH, biscuit waste (BW), corn and experimental rations (on DM basis \%).

\begin{tabular}{|c|c|c|c|c|c|c|c|}
\hline Items $(\%)$ & DM & OM & $\mathrm{CF}$ & $\mathrm{CP}$ & $\mathrm{EE}$ & NFE & Ash \\
\hline \multicolumn{8}{|l|}{ Tested materials: } \\
\hline $\mathrm{CH}$ & 90.85 & 88.40 & 24.13 & 15.20 & 2.43 & 48.95 & 11.60 \\
\hline BW & 92.10 & 98.90 & 1.10 & 8.78 & 8.01 & 81.01 & 1.10 \\
\hline Corn & 88.84 & 98.68 & 1.98 & 8.01 & 3.41 & 85.28 & 1.32 \\
\hline \multicolumn{8}{|c|}{ Concentrate feed mixture (CFM): } \\
\hline CFM1(control) & 91.77 & 90.97 & 12.03 & 13.85 & 3.01 & 62.08 & 9.03 \\
\hline CFM2 & 91.84 & 91.16 & 11.48 & 13.34 & 4.72 & 61.62 & 8.84 \\
\hline CFM3 & 91.90 & 91.34 & 11.02 & 14.03 & 5.15 & 61.14 & 8.66 \\
\hline \multicolumn{8}{|c|}{ Experimental rations*: } \\
\hline $\mathrm{R} 1$ (control) & 91.40 & 89.94 & 16.87 & 14.39 & 2.78 & 56.83 & 10.06 \\
\hline $\mathrm{R} 2$ & 91.44 & 90.06 & 16.54 & 14.08 & 3.80 & 56.55 & 9.94 \\
\hline R3 & 91.48 & 90.16 & 16.26 & 14.50 & 4.06 & 55.34 & 9.84 \\
\hline
\end{tabular}

*R1: $60 \%$ CFM1 + 40\% CH: R2: 60\% CFM2 + 40\% CH: R3: 60\% CFM3 + 40\% CH

\section{Digestibility trials:-}

Nutrients digestibility and feeding values of the experimental diets were determine by using three animals from each treatment in digestibility trials by using acid insoluble ash (AIA) technique as internal marker according to Van- Keulen and young (1977). Fecal samples were collected from the rectum at 3 days as collection period. Representative samples of feed and feces from the whole collection period were prepared for proximately analysis according to A.O.A.C. (1995).

\section{Blood and milk sample analyses:}

Samples of blood were collected at the end of the experiment in sterile blood tubes and immediately centrifuged at $4000 \mathrm{rpm}$ for 15 minutes. Plasma was carefully taken after treated by ethylene diamine tetra acetic acid EDTA and then stored at $-20^{\circ} \mathrm{C}$ until analysis to obtain serum. plasma immediately frozen for subsequent biochemical analysis. Blood parameters, including total protein, liver function , kidney function, high density lipoprotein and low-density lipoprotein, were measured by using enzymatic procedures and commercial kits.

Daily milk yield was recorded manually and milk sample were collected at first, middle and end of experiment for analysis of milk composition using Milko Scan (model 130 series - type 10900 FOSS electric - Denmark),

\section{Statistical analysis:}

Analysis of variance (one-way, ANOVA) was performed to compare between different groups .Statistical analysis was carried out using SAS (2001) and Duncan's multiple range Test (Duncan, 1955) was used to separate the means when the main effect was significant.

\section{RESULTS AND DISCUSSION}

Data in Table (2) showed the chemical composition of biscuit waste, other ingredients and tested rations. The proximate analysis of biscuit waste agreed with Giromini et al (2017) that lipid content ranged from $10 \%$ to $12 \%$, nearly three times than wheat and corn, starch content can be up to $50 \%-60 \%$ on dry matter basis (DM) and DM ranged from $79 \%$ up to $93 \%$ depending on types of the bakery waste (bread, cakes, cookies, flour), and their ingredient (egg, oils , cream and sugars) during the processing before using it in animal nutrition.

Results showed that all concentrate feed mixtures (CFM) had slightly differences in all proximate analysis except $\mathrm{EE}$ content which increase with increasing the level of BW in CFM.

Tested ration (R2 and R3) showed the high content of fats and low content of crude fiber than control, this may be due to increase the percent of addition of (BW) instead of corn in CFM. This agree with 
finding of Humer et al (2017) who found an increase in fat content in ration from 2.5 to $7.1 \%$ when increase level of bakery waste instead of grains by $45 \%$ in ration.

Table (3): Digestion coefficients and nutritive values of the experimental diets.

\begin{tabular}{lcccc}
\hline Item & \multicolumn{3}{c}{ Treatment } \\
\cline { 2 - 5 } Dry matter intake(DMI) (g/ d): & R1 & R2 & SEM \\
CFM & 846 & 824 & 812 \\
Clover hay (CH) & & & \\
& 564 & 558 & 546 \\
Digestion coefficients (\%): & & & \\
DM & & & \\
OM & $70.30^{\mathrm{b}}$ & $72.84^{\mathrm{a}}$ & $70.81^{\mathrm{b}}$ & 0.45 \\
CP & 69.68 & 68.14 & 67.87 & 0.40 \\
CF & $66.65^{\mathrm{c}}$ & $70.68^{\mathrm{a}}$ & $68.91^{\mathrm{b}}$ & 1.09 \\
EE & $66.91^{\mathrm{a}}$ & $62.96^{\mathrm{b}}$ & $59.52^{\mathrm{c}}$ & 0.60 \\
NFE & $73.15^{\mathrm{b}}$ & $76.77^{\mathrm{a}}$ & $71.92^{\mathrm{b}}$ & 0.96 \\
Feeding values on DM basis (\%): & $72.77^{\mathrm{b}}$ & $74.74^{\mathrm{a}}$ & $74.66^{\mathrm{a}}$ & 0.52 \\
TDN & & & & \\
DCP & $66.87^{\mathrm{b}}$ & $69.19^{\mathrm{a}}$ & $67.64^{\mathrm{ab}}$ & 0.44 \\
\hline
\end{tabular}

a,b,c : Means of different superscripts in the same row are significant $(\mathrm{P}<0.05)$ different.

Digestion coefficients and nutritive values were presented in table (3) Dry matter digestibility was significantly increased $(\mathrm{P}<0.05)$ in $(\mathrm{R} 2)$ and this agreed with Champe and Church $(1980)$ who found that an increase in DM apparent digestibility followed the replacement of corn by bakery waste. while, Carneiro et al (2006) reported no effect with replacement of the corn by bakery by products up to $80 \%$ on DM apparent digestibility in sheep, while there was no significant difference in OM digestibility between treatments.

Crude protein digestibility showed that there was significant increase $(\mathrm{P}<0.05)$ in $\mathrm{R} 2$ and $\mathrm{R} 3$ by 6.05 and $3.40 \%$, respectively compared to control .This may be due to feeding sugars content in BW instead of starch in corn in ration which adjust rumen $\mathrm{pH}$ and improve $\mathrm{N}$ utilization efficiency, this agreed with the finding of Cabral et al (2000) who found that the decrease in ruminal $\mathrm{NH}_{3}-\mathrm{N}$ concentration when using bakery waste in the ration may be related to the increase in energy availability for microbial protein synthesis. On the other hand digestibility of CF was decreased by increasing level of $\mathrm{BW}$ in rations $\mathrm{R} 2$ and R3 by 5.90 and $11.04 \%$, respectively compared to control, this may be due to the high fat content and fats (oils and butter) of BW compared to the traditional ingredients used in ruminant feeding as it had adverse effect on the abundance of fibriolytic bacteria (Humer et al, 2018) who found a higher level of bakery by products (45\%) which reduced rumen microbiota (genus Butyrivibrio) and impaired fiber degradation and ruminal fermentation. There was no significant difference between R1(control) and R3 but R2 was increased by $4.99 \%$ compared with control on EE digestibility, this may be due to the high energetic content of BW from fats and soluble carbohydrates. This agreed with Carneiro et al (2006) when using bakery by products in sheep diets with $17.7 \% \mathrm{EE}$ and they found greater value of EED than control . Also, Champe and Church (1980) found an increased in EE digestibility when adding the bakery waste at the rate of 0,20 and $40 \%$ being 19.4, 60.0 and $73.2 \%$, respectively. Data of NFE showed there was significant increase with R2 and R3 compared with control, this may be caused by its sugars content which are water-soluble carbohydrates, and include disaccharides (sucrose and lactose ) and mono saccharides (glucose and fructose) which fermented quickly in the rumen. (Oba, 2011).

Results of TDN showed significant increase for R2 compared to control, while there were no significant difference between $\mathrm{R} 2$ and $\mathrm{R} 3$ and between $\mathrm{R} 1$ and $\mathrm{R} 3$, these results may be due to the increase in digestion coefficient of rations R2 and R3 by adding BW. This agreed with the finding of Almira et al (2012) that value of TDN of the bakery by-products was higher compared with corn meal and this increase may be related to from bakery by- products that included the energetic mixture of the concentrate. While there was no significant differences among treatments in DCP

\section{Milk production and composition:}

Table (4) observed an increased in milk production by $14.75 \%$ for R 2 and decreased by $10.16 \%$ for R3 as compared with control, this agreed with the finding of (Kaltenegger et al, 2020) when inclusion 15 or $30 \%$ of BW in diet of dairy cows, whereas increased energy density from increasing the fat and sugar content in the ration. Replacement of $3 \%$ plant oil for equal amount of corn in a ration with 1.55 Mcal 
$\mathrm{NEl} / \mathrm{kg} \mathrm{DM}$ amounts to a 7\% increasing energy concentration (Andrés et al, 2011). Values of fat corrected milk (FCM) showed that R2 had significant increase compared with control and R3 could be resulted from increasing fat content in milk (60.20 g/day) in this treatment (R2).

Table (4): Daily milk yield, milk composition and milk constituent's yield of lactating goats during experimental period.

\begin{tabular}{|c|c|c|c|c|}
\hline \multirow{2}{*}{ Item } & \multicolumn{3}{|c|}{ Treatment } & \multirow[t]{2}{*}{$\pm \mathrm{SE}$} \\
\hline & R1 & $\mathrm{R} 2$ & R3 & \\
\hline Daily milk yield (Kg/day) & $1.614^{\mathrm{b}}$ & $1.852^{\mathrm{a}}$ & $1.450^{\mathrm{c}}$ & 59.25 \\
\hline Daily 4\%-FCM yield (K g/day) & $1.375^{\mathrm{b}}$ & $1.646^{\mathrm{a}}$ & $1.267^{\mathrm{b}}$ & 62.03 \\
\hline \multicolumn{5}{|l|}{ Milk composition: } \\
\hline Fat ,\% & 3.00 & 3.25 & 3.15 & 0.12 \\
\hline Protein, $\%$ & $2.48^{\mathrm{a}}$ & $2.33^{\mathrm{b}}$ & $2.29^{c}$ & 0.74 \\
\hline Lactose , \% & $3.94^{\mathrm{ab}}$ & $3.83^{\mathrm{b}}$ & $4.06^{\mathrm{a}}$ & 0.17 \\
\hline Total solids , \% & 10.19 & 9.88 & 10.33 & 0.17 \\
\hline Solids not fat , $\%$ & 7.19 & 6.63 & 7.18 & 1.45 \\
\hline Ash , \% & 0.77 & 0.73 & 0.79 & 0.37 \\
\hline \multicolumn{5}{|l|}{ Milk Constituents yield ( $\mathrm{g} /$ day): } \\
\hline Fat & $48.83^{b}$ & $60.20^{\mathrm{a}}$ & $45.68^{c}$ & 2.37 \\
\hline Protein & $40.02^{\mathrm{b}}$ & $43.16^{\mathrm{a}}$ & $33.20^{\mathrm{c}}$ & 1.88 \\
\hline Lactose & $63.59^{\mathrm{b}}$ & $70.94^{\mathrm{a}}$ & $58.87^{\mathrm{c}}$ & 1.12 \\
\hline Total solids yield & $166.9^{\mathrm{b}}$ & $183.00^{\mathrm{a}}$ & $149.80^{c}$ & 4.92 \\
\hline Solids not fat yield & $116.1^{\mathrm{b}}$ & $122.80^{\mathrm{a}}$ & $104.1^{\mathrm{c}}$ & 2.73 \\
\hline
\end{tabular}

$a, b, c:$ Means of different superscripts in the same row are significantly $(P<0.05)$ different Fat corrected milk in sheep and goats according to (Marrogenis and papachristoforoy (1980) : FCM (4\%) Kg = milk yield $(\mathrm{Kg}) *$ $(0.411+0.147 *$ fat $\%$.

There was no significant differences in milk fat content between groups, this agreed with resulted obtained by Dhiman et al (2000) who found a quadratic increase in milk fat $\%(3.44 \%, 3.60 \%, 3.56 \%$, $2.86 \%$, and $2.93 \%$ ) as result to increasing levels of soybean oil in the rations (control, $0.5 \%, 1 \%, 2 \%$, and $4 \%$ oil), these resulted from the effect of oil that limit the growth of cellulolytic bacteria which hydrogenate the oil consumed and toxic effect of unsaturated FA on their growth. Meanwhile, there was significant decrease in protein content being 2.33 and 2.29 compared to 2.48 for control, this due to a dilution effect of increasing milk production as result of the increasing fat, as well as a shortage of available amino acids for the synthesis of protein. To maintain pace with the decreasing milk production. This agreed with the finding of Zhang et al (2006) who found that feeding ewes sunflower seeds led increasing in protein and casein being $(46.5 \mathrm{~g} / \mathrm{kg}$ and $35.4 \mathrm{~g} / \mathrm{kg})$ while control being $(47.6 \mathrm{~g} / \mathrm{kg}$ and 36.7 $\mathrm{g} / \mathrm{kg}$ ) and $(47.1 \mathrm{~g} / \mathrm{kg}$ and $36.1 \mathrm{~g} / \mathrm{kg}$ ) when supplemented diet with linseed oil, while there was no significant differences in lactose, total solids and solids not fat between treatments.

\section{Blood parameters:}

As shown in Table (5) the values of total proteins and albumin were 6.47, 7.14 and $7.88 \mathrm{~g} / \mathrm{dL}$ and 3.42 , 3.87 and $4.25 \mathrm{~g} / \mathrm{dL}$ for control , R2 and R3, respectively. Increased the TP and albumin were increased $(\mathrm{P}<0.05)$ with R2, R3 groups compared to the control . Zeedan et al (2010) showed that the total plasma protein was increased as result of increased oil or fat in the diets in small ruminant and buffaloes, while there no significantly differences in globulin in blood.

The values of results showed no significant effects on plasma AST and ALT concentrations with different treatments, this indicates that goats were in normal health without any adverse effects of (BW) 


\section{Sayed et al.}

supplementation on liver function, this agree with Osman et al (2020) who found that values of AST and ALT in normal range when increasing molasses levels in ration.

urea and creatinine concentrations were in the normal range, urea and creatinine not affected with experimental rations compared to control

Supplemented groups had significantly increase in concentrations of cholesterol and triglycerides. These results are in agreement with those found by El-Bedawy et al. (2005) as increasing protected fat levels to $4 \%$ or $8 \%$ in ration.

Table (5): Blood plasma parameters as affected by feeding the experimental rations.

\begin{tabular}{lcccc}
\hline \multirow{2}{*}{ Parameter } & \multicolumn{3}{c}{ Experimental group } & \multirow{2}{*}{ \pm SE } \\
\cline { 2 - 4 } & $\mathrm{R} 1$ & $\mathrm{R} 2$ & $\mathrm{R} 3$ & \\
\hline Total protein (g/dL) & $6.47 \mathrm{c}$ & $7.14 \mathrm{~b}$ & $7.88 \mathrm{a}$ & 0.58 \\
Albumin (g/dL) & $3.42 \mathrm{c}$ & $3.87 \mathrm{~b}$ & $4.25 \mathrm{a}$ & 0.44 \\
Globulin (g/dL) & 3.05 & 3.27 & 3.63 & 0.55 \\
ALT (IU/L) & 14.44 & 14.37 & 14.41 & 0.89 \\
AST (IU/L) & 22.12 & 22.65 & 22.17 & 1.44 \\
Urea (mg/dL) & 7.13 & 7.84 & 7.87 & 0.83 \\
Creatinine (g/dL) & 1.18 & 1.12 & 1.58 & 0.95 \\
Cho (mg/dl) & $128.55 \mathrm{c}$ & $135.28 \mathrm{~b}$ & $145.39 \mathrm{a}$ & 0.41 \\
HDL & $72.48 \mathrm{c}$ & $75.71 \mathrm{~b}$ & $88.53 \mathrm{a}$ & 0.35 \\
LDL & 37.61 & 39.87 & 33.22 & 4.17 \\
TG, mg/dl & $92.28 \mathrm{c}$ & $98.46 \mathrm{~b}$ & $118.21 \mathrm{a}$ & 1.27 \\
\hline
\end{tabular}

$a, b$ and $c:$ Means within the same row with different superscripts are significantly $(P<0.05$ different $)$.

Table (6): Feed intake (as fed) and economical evaluation of dams during the suckling period (90 days).

\begin{tabular}{|c|c|c|c|}
\hline \multirow{2}{*}{ Item } & \multicolumn{3}{|c|}{ Experimental rations } \\
\hline & $\mathrm{R} 1$ & $\mathrm{R} 2$ & R3 \\
\hline \multicolumn{4}{|l|}{ Average daily feed intake, g/ dam/day (as fed): } \\
\hline CFM & 846 & 824 & 812 \\
\hline Clover hay $(\mathrm{CH})$ & 564 & 558 & 546 \\
\hline Daily milk yield, g/ dam/day & $1614.2^{\mathrm{b}}$ & $1852.3^{\mathrm{a}}$ & $1450.2^{\mathrm{c}}$ \\
\hline \multicolumn{4}{|l|}{ Economical evaluation: } \\
\hline \multicolumn{4}{|l|}{ Average total feed cost, LE/dam/ day: } \\
\hline $\mathrm{CFM}$ & 3.98 & 3.70 & 3.49 \\
\hline Clover hay $(\mathrm{CH})$ & 1.58 & 1.56 & 1.53 \\
\hline Total feed cost, LE/dam/day & 5.56 & 5.26 & 5.02 \\
\hline Price of average daily milk (LE/dam/day) & 9.69 & 11.11 & 8.70 \\
\hline Feed cost / kg milk, L.E. & 3.44 & 2.84 & 3.46 \\
\hline \multicolumn{4}{|c|}{$\begin{array}{l}\text { a, } b \text { and } c: \text { Means within the same row with different superscripts are significantly different }(P<0.05) \text {. } \\
\text { prices of concentrate feed mixture }(C F M 1), \text { concentrate feed mixture }(C F M 2) \text {, concentrate feed mixture }(C F M 3) \\
\text { clover hay }(C H) \text { were } 4700,4500,4300 \text { and } 2800 L \text { L. } \text {./ton, respectively based on the market price in } 2020 \text { and } 6 \\
\text { LE/kg raw milk. } \\
R 1: \text { control rations }(60 \% C F M+40 \% C H), R 2: C F M(20 B W)+C H) R 3: C F M(40 B W)+C H) \text {. } \\
\text { Total daily feed cost }(\text { L.E. })=(\text { cost of } C F M+\text { clover hay }) \text {. }\end{array}$} \\
\hline
\end{tabular}

Economical evaluation was showed in Table (6) data reported that R3 had the lowest feed cost being $5.02 \mathrm{LE} /$ dam/day but R2 had significantly increase in price of average daily milk by $14.7 \%$ compared with control and also, had lowest feed cost that mean that the cost of producing $\mathrm{Kg}$ of milk being 2.84 L.E

\section{CONCLUSION}

It could be concluded from the previous results that replaced corn by biscuits wastes around of $20 \%$ in concentrate feed mixture in dairy goats diets had better economic efficiency without negative effect on milk yield and its composition. 


\section{REFERENCES}

Almira B. F. ; J. F. M.Mirton ; C. F. L Fernando.; S. M. Afrani; A. M.Danilo; M. F. Bruna ; S. C. Luciano and E. M. F. Carlos (2012) Bakery waste in sheep diets: intake, digestibility, nitrogen balance and ruminal parameters R. Bras. Zootec., v.41, n.1, p.147-153

Andrés L M.; P. H. Manuel; M. A. Luis; C. P.Domingo; I. S. Ana and G. C. Gustavo (2011) Fat addition in the diet of dairy ruminants and its effects on productive parameters Rev Colomb Cienc Pecu 2013; 26:69-78

A O A C (1995). Methods of Analysis. Vol. 1: Agricultural Chemicals, Contaminats, Drugs. 16th ed. Washington, D.C. USA.

Arosemena, A.; E. DePeters, and J. Fadel. (1995). Extent of variabil- ity in nutrient composition within selected by-product feedstuffs. Anim. Feed Sci. Technol. 54:103-120.

Cabral, L.S.; S.C.V. Filho and P.A.M. Malafaia (2000) Frações protéicas de alimentos tropicais e sua taxas de digestão estimada pela incubação com proteases ruminais. Revista Brasileira de Zootecnia, v.26, n.6, p.2316-2324,.

Caio S. T.; M. Y.Caroline; B.Amanda; J. Melissa; S.Maggie; A. W. Tryon; J. V. Michael and J. B. Barry (2019) Feeding Dairy Cows With "Leftovers"and the Variation in Recovery of Human-Edible Nutrients in Milk | Volume 3 | Article 114

Carneiro, M.S.S.; A.H. Oliveira and R.O. Sales (2006). Valor nutritivo de rações para ovinos com quatro níveis do resíduo de panificação. In: REUNIÃO ANUAL DA SOCIEDADE BRASILEIRA DE ZOOTECNIA, 43., João Pessoa. Anais... João Pessoa: Sociedade Brasileira de Zootecnia,. p.1-3.

Champe, K.A. and D.C. Church ( 1980). Digestibility of dried bakery product by sheep. Journal of Animal Science, v.51, n.1, p.25-27,

Deise S. C. ; M. R. Cláudia; M. J. Alaor; O. M. Francisco; C. B. Gustavo; J. M. Marcel and G. T. Luís (2017) Waste from the biscuit and noodle industries in Nile tilapia diets. Ciências Agrárias, Londrina, v. 38 , n. 4, p. 2151-2162

Dhiman T.R. ; L.D. Satter; M.W. Pariza; M.P. Galli; K Albright and M.X. Tolosa (2000). Conjugated linoleic acid (CLA) content of milk from cows offered diets rich in linoleic and linolenic acid. J Dairy Sci., 83:1016-1027.

Duncan, D. B. (1955).Multiple ranges and multiple F test. Biometrics, 11:1-20.

El-Bedawy, T.M. ;I. A. Gomrnaa; Sabbah M. Allam and F.M. Abu-Donia (2005). Production of calcium salts of fatty acid from soap-stock on semi industrial scale and its use in finishing rations of Friesian bulls. Egyptian J. Nutrition and Feeds (200.1) 8 (2): 175-185

Elferink, E.; S. Nonhebel and H. Moll (2008). Feeding livestock food residue and the consequences for the environmental impact of meat. J. Clean. Prod. 16 (12), 1227-1233.

Ertl, P.; Q. Zebeli ; W. Zollitsch, and W. Knaus (2015). Feeding of by-products completely replaced cereals and pulses in dairy cows and enhanced edible feed conversion ratio. J. Dairy Sci., 98, 12251233.

Humer, E.; S. Aditya; A. Kaltenegger; F. Klevenhusen, R. Petri and Q. Zebeli (2018).Graded substitution of grains with bakery by-products modulates ruminal fermentation, nutrient degradation, and microbial community composition in vitro. J. Dairy Sci., 101 (4), 308-309.

Kaltenegger, A.; E. Humer; A. Stauder and Q. Zebeli (2020). Feeding of bakery byproducts in the replacement of grains enhanced milk performance, modulated blood metabolic profile, and lowered the risk of rumen acidosis in dairy cows. J. Dairy Sci., 103 (11), 10122-10135

Marrogenis, A. P. and C. papachristoforoy (1980).Estimation of the energy value of milk production of fat corrected milk yield in sheep and goats.Small Ruminant Research(3) 229-236.

Oba, M. (2011). Review: Effects of feeding sugars on productivity of lactating dairy cows. Can. J. Anim. Sci. 91: 37_46.

Organization, W.H., (2019). Hazards associated with animal feed: report of the Joint FAO/WHO expert meeting, 12e15 May 2015, FAO headquarters. Food \& Agriculture Org, Rome, Italy. 


\section{Sayed et al.}

Osman A.; Nawal M. E. and A. A. Khalid (2020) Effects of dietary supplementation with different concentration of molasses on growth performance, blood metabolites and rumen fermentation indices of Nubian goats . BMC Veterinary Research 16:411

Pinotti, L.; C. Giromini ; M. Ottoboni ; M. Tretola and D. Marchis (2019a). Review: insectsm and former foodstuffs for upgrading food waste biomasses/streams to feed ingredients for farm animals. Animal 13 (7), 1365-1375.

Romero-Huelva, M.; M. A. Ramírez-Fenosa; R. Planelles-González ; P. García- Casado and E. MolinaAlcaide (2017). Can by-products replace conventional ingredients in concentrate of dairy goat diet? J. Dairy Sci. 100, 4500-4512

SAS (2001). Statistical Analysis System SAS User,s Guide Statistics SAS Institute Inc. Editors, Cary, NC.

Shittu M.D. ; O.O. Ojebiyi ; S.G. Ademola and T.K. Ojediran (2016) Replacement value of biscuit dough for maize on performance and nutrient utilization of broiler chickens International Journal of Science, Environment and Technology, Vol. 5, No 3, 2016, 1057 - 1065

Van- Keulen and B. A. Young (1977) Evaluation of acid-insoluble ash as neutral marker in ruminant digestibility studies .J. Anim. Sci., 44: 282.

Van Zanten, H.H.; H. Mollenhorst ; D.G. Oonincx ; P. Bikker; B.G. Meerburg and I.J. Boer (2015). From environmental nuisance to environmental opportunity: housefly larvae convert waste to livestock feed. J. Clean. Prod. 102, 362-369.

Wing, J.M. (1965) Preliminary evaluation of dried bakery product in dairy cattle rations. Feedstuffs, v.37, n.19, p. 128 .

Zeedan, Kh. I.I.; O.F. Komonna; K.E.I. Etman and Kh. M. M. Mousa (2010). Effect of using differentlevels and sources of fats and roughages on productive performance, rumen fermentation and some blood parameters in ruminant. 1- Effect of dry fat supplementation on productive and reproductive performance of Damascus goats. Egyptian J. Nut. And Feeds, 13 (1): 21-40.

Zhang R.H.; A.F.Mustafa and X. Zhao (2006). Effects of feeding oilseeds rich in linoleic and linolenic fatty acids to lactating ewes on cheese yield and on fatty acid composition of milk and cheese. Anim Feed Sci. Tech., 127:220-23.

\section{إحلال مخلفات البسكويت كبديل للارة في علائق الماعز الامشقى}

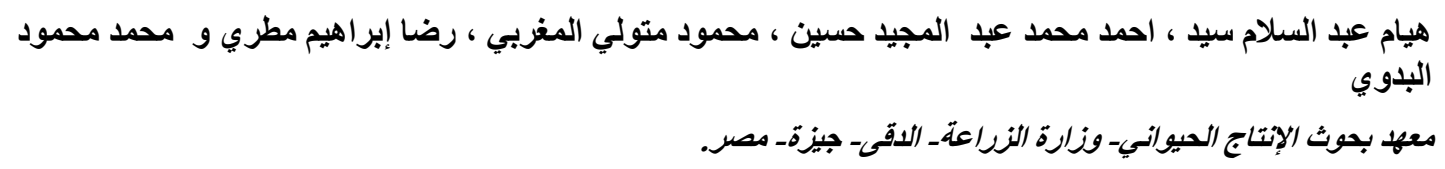

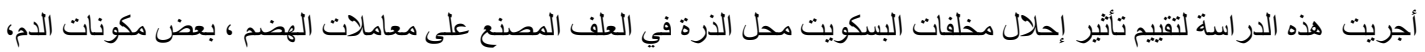

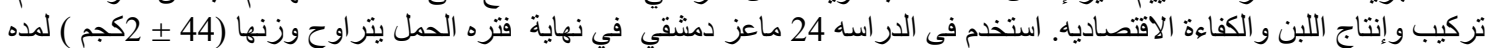

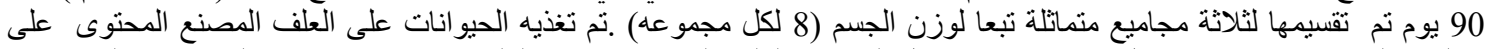

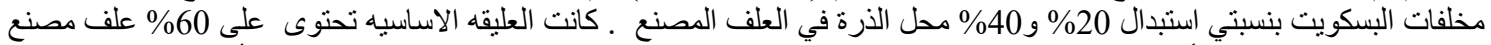

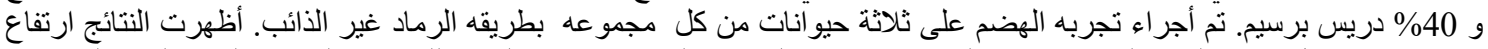

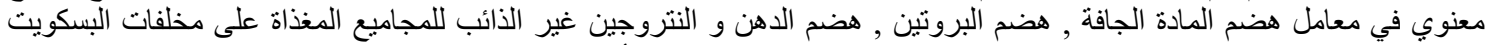

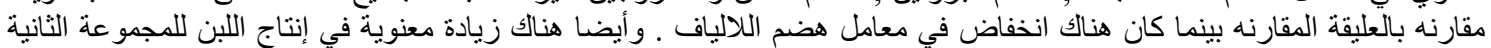

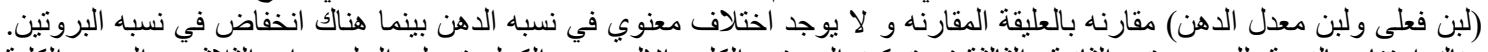

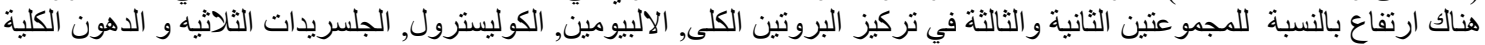

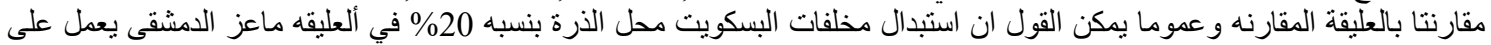

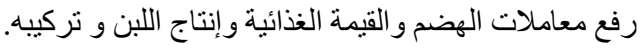

